University of Montana

ScholarWorks at University of Montana

8-1989

\title{
Mapping Regional Forest Evapotranspiration and Photosynthesis by Coupling Satellite Data with Ecosystem Simulation
}

\author{
Steven W. Running \\ Ramakrishna R. Nemani \\ David L. Peterson \\ Larry E. Band \\ Donald F. Potts \\ University of Montana - Missoula, Donald.potts@umontana.edu \\ See next page for additional authors
}

Follow this and additional works at: https://scholarworks.umt.edu/forest_pubs

Part of the Forest Management Commons

Let us know how access to this document benefits you.

\section{Recommended Citation}

Running, Steven W.; Nemani, Ramakrishna R.; Peterson, David L.; Band, Larry E.; Potts, Donald F.; Pierce, Lars E.; and Spanner, Michael A., "Mapping Regional Forest Evapotranspiration and Photosynthesis by Coupling Satellite Data with Ecosystem Simulation" (1989). Forest Management Faculty Publications. 12. https://scholarworks.umt.edu/forest_pubs/12

This Article is brought to you for free and open access by the Forest Management at ScholarWorks at University of Montana. It has been accepted for inclusion in Forest Management Faculty Publications by an authorized administrator of ScholarWorks at University of Montana. For more information, please contact scholarworks@mso.umt.edu. 
Authors

Steven W. Running, Ramakrishna R. Nemani, David L. Peterson, Larry E. Band, Donald F. Potts, Lars E. Pierce, and Michael A. Spanner 


\title{
MAPPING REGIONAL FOREST EVAPOTRANSPIRATION AND PHOTOSYNTHESIS BY COUPLING SATELLITE DATA WITH ECOSYSTEM SIMULATION ${ }^{1}$
}

\author{
Steven W. Running and Ramakrishna R. Nemani \\ School of Forestry, University of Montana, Missoula, Montana 59812 USA \\ DAVID L. Peterson \\ Mail Stop 242-4. NASA Ames Research Center, Moffett Field, California 94035 USA \\ LARRY E. BAND \\ Department of Geography, University of Toronto, Toronto, Ontario, Canada M5S 1AI \\ Donald F. Potts and Lars L. Pierce \\ School of Forestry: Lniversity of Montana, Missoula, Montana 59812 USA \\ AND \\ Michael A. SPANNER \\ Mail Stop 242-4, NASA Ames Research Center, Moffett Field, California 94035 USA
}

Abstract. Annual evapotranspiration (ET) and net photosynthesis (PSN) were estimated for a mountainous $28 \times 55 \mathrm{~km}$ region of predominantly coniferous forests in western Montana. A simple geographic information system integrated topographic, soils, vegetation, and climatic data at a $1.1-\mathrm{km}$ scale size defined by the satellite sensor pixel size. Leaf area index (LAI) of the forest was estimated with data from the NOAA (National Oceanic and Atmospheric Administration) Advanced Very High Resolution Radiometer (AVHRR). Daily microclimate of each cell was estimated from ground and satellite data and interpolated using MT-CLIM, a mountain microclimate simulator. A forest ecosystem simulation model, FOREST-BGC, was used to calculate ET and PSN daily for each cell. Ranges of estimated LAI (4-15), ET (25-60 cm/yr), and PSN (9-20 Mg $\left.\mathrm{ha}^{-1} \cdot \mathrm{yr}^{-1}\right)$ across the landscape follow the trends expected in both magnitude and spatial pattern. These estimates compared well with field measurements of related variables, although absolute validation of these predictions is not now possible at large spatial scales.

Key words: coniferous forest; ecosystem simulation; evapotranspiration; landscape ecology: leaf area index; photosynthesis; remote sensing.

\section{INTRODUCTION}

Evapotranspiration (ET) and Net Photosynthesis (PSN) are key processes controlling the exchange of energy and mass by terrestrial vegetation. ET provides the primary linkage between energy and hydrologic flux for a vegetated surface; PSN summarizes the efficiency of the exchange of carbon dioxide, and is directly related to the primary production of the vegetation. Largescale perturbations such as global climate change, regional air pollution, and land-use conversions affect biospheric processes at much larger scales than typically used in ecological studies (Shukla and Mintz 1982, Mathews 1983, Woodwell et al. 1983, Sellers et al. 1988). Regional flux rates of carbon dioxide and water from terrestrial vegetation must be known in order to understand the interaction of the biosphere with the global atmosphere and hydrosphere.

Most calculations of the flux of energy and mass from terrestrial ecosystems have been executed at two dif-

\footnotetext{
${ }^{1}$ Manuscript received 3 April 1988; revised 22 August 1988; accepted 23 August 1988.
}

ferent spatial scales. First, global scale computer models for climate (Manabe and Weatherald 1980) or for the global carbon cycle (Moore et al. 1981, Emmanuel et al. 1984) treat the entire land surface as a single entity or as discrete units of $\approx 1^{\circ}$ latitude by $1^{\circ}$ longitude. Considerable work has been done at the other spatial extreme, single-plant to stand-level models of ecosystems (Golkin and Ewel 1984, Mohren et al. 1984, Pastor and Post 1986). We feel it is necessary to model rates of ET and PSN at an intermediate scale in order to link processes to global models and make them more dynamic and reactive to changing conditions of surface climate, vegetation cover, and vegetation health (Running 1986).

The appropriate intermediate scale is hard to determine as it depends on the process being modeled, the inherent variation in subscale phenomena, data availability at different scales, and computational limitations. At regional scales the only appropriate instruments for developing a continuous database are satellite or aircraft-based sensors. Remote sensing provides the needed dynamic temporal view of vegetation, and 
complete spatial coverage that eliminates the need for regional extrapolations from small data sets. Discrimination and classification of major biome types and estimation of structural variables such as leaf area index (LAI) are now possible (Tarpley et al. 1984, Justice et al. 1985, Tucker et al. 1985, Peterson et al. 1987). LAI is an important structural characteristic for quantifying energy and mass exchange of plant canopies by satellite (Wittwer 1983, Botkin 1986).

The role of vegetation in controlling energy and mass exchange rates from land surfaces depends on physiological characteristics of the vegetation as well as climate (Jarvis and McNaughton 1986, Running 1986, Sellers et al. 1986). Mechanistic models of vegetation that include physiological responses usually provide the most rigorous estimates of energy and mass fluxes. For example, ET can be estimated with a PriestleyTaylor approach, where potential ET is scaled to actual ET with an empirically defined alpha factor. This alpha factor must represent all the variabilities of species, leaf area, stomatal conductance, root uptake capacities, etc., present in an ecosystem. Similar empirical approaches have been used to estimate Net Primary Production (NPP); Leith (1975) defined global NPP as a nonlinear function of an estimated actual ET. Extrapolating from a process-level model, Terjung et al. (1976) developed a photosynthesis model for the entire world, and Band et al. (1981) calculated regional photosynthesis in California. Dunin and Aston (1984) extrapolated a process model of ET over $2700 \mathrm{~km}^{2}$. However, these earlier attempts treated the landscape as extensive, homogeneous vegetation because these scientists did not have the benefit of satellite sensors to estimate the actual vegetation cover of the study regions. Improvements have also been made recently in extrapolating climatic variables such as radiation, humidity, temperature, and precipitation across landscapes (Running et al. 1987).

The objectives of this paper are to develop a methodology for integrating biophysical information from diverse sources, and to execute an ecosystem model over landscape scales. To pursue this goal we segmented the $28 \times 55 \mathrm{~km}$ study area into 1200 units, each defined by satellite as homogeneous vegetation. We then calculated or collected the climate and soil data necessary to run the model, and created a simple Geographic Information System (GIS) with each grid cell defined by the above attributes. Finally, for each grid cell, we ran the ecosystem model FOREST-BGC (Running and Coughlan 1988) and mapped the model outputs of annual evapotranspiration and net photosynthesis for the landscape.

\section{Methods \\ Study area}

The study area surrounds the northern half of Flathead Lake in northwestern Montana. Climatic influ- ences on vegetation are pronounced because three parallel mountain ranges separated by forested valleys create strong temperature and precipitation gradients across a short distance (Fig. 1a). Bedrock in the study area is meta-sedimentary and structurally controlled by block faulting. Faulting has formed two major mountain ranges, the Mission Range and the Swan Range, with an intermountain valley in the eastern half of the study area. The western half of the study area is characterized by the folded and cross-faulted Salish Mountains and Flathead Lake.

The climate in this region is dominated by the interaction of Pacific Ocean air masses with the mountain ranges. While the Mission Mountains produce some orographic precipitation, the Swan Mountains are the major barrier for ocean air and receive the highest rainfall and snow (Fig. 1a). These mountain ranges result in a high gradient of precipitation, $65-200 \mathrm{~cm}$ within the study area. Valley bottoms receive $50 \%$ of annual precipitation as rain, while high-elevation sites received $>70 \%$ of annual precipitation as snow. Soils seldom freeze because autumn snows insulate the surface from air temperature extremes. Night minimum air temperatures remain $<0^{\circ} \mathrm{C}$ for at least $200 \mathrm{~d}$ annually, and absolute minima of $\leq-40^{\circ}$ occur each year. The potential physiological growing season, which we define by noncontinuous days of night air temperature $>0^{\circ}$, starts in late April and extends to mid-October, but night frosts are possible on almost any night during this period. At this latitude. $47^{\circ} \mathrm{N}$, day length ranges from $8.5 \mathrm{~h}$ in December to $15.5 \mathrm{~h}$ in June, with relatively cloudy winters and clear summers.

Elevation influences forest composition on these sites. Ponderosa pine (Pinus ponderosa Laws.), and Douglasfir (Pseudotsuga menziesii Franco) are adapted to the lower elevation, warmer sites, whereas lodgepole pine (Pinus contorta Dougl.), subalpine fir (Abies lasiocarpa Nutt.) and white bark pine (Pinus albicaulis Dougl.) are adapted to cold, moist sites. Grand fir (Abies grandis Lindl.), western red cedar (Thuja plicata Donn), western larch (Larix occidentalis Nutt.), and western hemlock (Tsuga heterophylla Sarg.) occur at intermediate elevation.

Choice of spatial scale was primarily determined by satellite data and computational requirements. We divided the study area into square cells corresponding to the resolution of the AVHRR (NOAA Advanced Very High Resolution Radiometer) data, 1.1-km scale size, and computed average surface attributes and fluxes for these cells. We chose a $1.1-\mathrm{km}$ size because the usefulness of AVHRR data is well documented for monitoring vegetation at regional to continental scales (Norwine and Greegor 1983, Goward et al. 1985, Justice et al. 1985, Tucker et al. 1985). Also, data for accurate mapping of the spatial distribution of some of the model inputs, e.g., soil water-holding capacity, are unavailable at smaller scales such as Landsat TM (Thematic Mapper, $30 \mathrm{~m}$ ) or MSS (Multispectral Scan- 
ner, $80 \mathrm{~m}$ ). Finally, increasing the spatial resolution from $1.1 \mathrm{~km}$ to $30 \mathrm{~m}$ would require definition of 134444 times as many grid cells, so it is only justifiable if substantially improved results are produced. We are currently studying how the precision of certain surface flux calculations changes with variable landscape partitioning.

\section{ECOSYSTEM MODEL}

FOREST-BGC (BioGeochemical Cycles) is a process-level, ecosystem simulation model that calculates the cycling of carbon, water, and nitrogen through forest ecosystems (Running and Coughlan 1988). The model requires daily data for standard meteorological conditions, maximum-minimum temperatures, dew point, incident shortwave radiation and precipitation, and definition of key site and vegetation variables. The model calculates canopy interception and evaporation, transpiration, soil outflow of water; photosynthesis, growth and maintenance respiration, allocation, litterfall, and decomposition of carbon; and deposition, uptake, litterfall, and mineralization of nitrogen. The model has a mixed-time resolution, with hydrologic, photosynthetic, and maintenance respiration processes computed daily, and the other carbon and all nitrogen processes computed yearly. For this study, the important parts of the model are the hydrologic balance, evapotranspiration and canopy water stress, and photosynthesis.

As a brief summary of the model's function, daily precipitation is routed to snowpack or soil dependent on air temperature. A canopy interception fraction based on leaf area index is subtracted and evaporated, and the remaining water goes to a soil compartment where it is available for transpiration. Forest soils in this region have a high surface infiltration capacity, so overland flow is rare. Transpiration is calculated with a Penman-Monteith equation incorporating radiation and vapor pressure deficit drivers for evaporation. The canopy conductance term is a complex function of air temperature, vapor pressure deficit, incident radiation, and leaf water potential. Air temperatures $<0^{\circ} \mathrm{C}$ reduce canopy conductance to cuticular values, and are an important determinant of the growing season length. Canopy conductance is linearly reduced to a default cuticular value when either average daily vapor pressure deficit exceeds 1.6 MPa, or predawn leaf water potential, estimated from soil water availability, decreases below $-1.65 \mathrm{MPa}$. Aerodynamic conductance is fixed at $0.2 \mathrm{~m} / \mathrm{s}$ in the Penman-Monteith equation.
Canopy photosynthesis is calculated by multiplying a $\mathrm{CO}_{2}$ diffusion gradient by a mesophyll $\mathrm{CO}_{2}$ conductance and the canopy water vapor conductance, both of which are controlled by radiation and temperature. The light response surface for mesophyll conductance is asymptotic, with half maximum photosynthesis at $9720 \mathrm{~kJ} \cdot \mathrm{m}^{-2} \cdot \mathrm{d}^{-1}$. A light attenuation of $-0.5 / \mathrm{LAI}$ is used for Beers law attenuation of incident radiation to produce canopy average radiation. The inverse parabolic temperature response surface has an optimum of $20^{\circ}$, with high and low compensation points of $0^{\circ}$ and $40^{\circ}$, respectively. Net photosynthesis (PSN) is computed by subtracting a maintenance respiration term, calculated as an exponential function of air temperature with a $Q_{10}=2.3$ for all stem and root biomass, and then subtracting $35 \%$ of the remaining gross photosynthesis for growth respiration. As the complete model is rather large, further details can be found in Running and Coughlan (1988), or by contacting the authors. Because the primary interest in this study is seasonal photosynthesis and evapotranspiration, only the daily half of the model was used. The only output we will show from the model are maps of annual evapotranspiration and net photosynthesis and the seasonal trends of ET and PSN for cells representative of the range of flux rates.

\section{MODEL INPUTS}

To execute the model for each grid cell, we needed data for one canopy parameter, leaf area index, and one site parameter, soil water-holding capacity, along with daily climatic data. The necessary data and their sources along with the preprocessing necessary to produce grid cell specific data are shown in Fig. 2.

\section{Leaf Area Index (LAI)}

LAI is an important variable in the following FOREST-BGC process calculations: canopy interception and evaporation, transpiration, canopy light attenuation, photosynthesis, and canopy nitrogen content. The only feasible way to estimate LAI on a regional scale is from satellite-based sensors. The AVHRR on board the NOAA satellites provides daily coverage, and $1.1-\mathrm{km}$ spatial resolution, an appropriate scale for regional vegetation analysis (Hayes 1985). The AVHRR sensor best discriminates vegetation using various combinations of two sensor bands that measure reflectance in the near-infrared (NIR, $0.725-1.1 \mu \mathrm{m}$, Channel 2) and red (RED, $0.55-0.68 \mu \mathrm{m}$, Channel 1) wave-

FIG. 1. (a) A schematic diagram showing prominent physiographic features, average elevation of mountain ranges, and annual precipitation (black bars) patterns for the $1540-\mathrm{km}^{2}$ study site. Geographical features in the top panel are, from left to right, the Salish Mountains, Flathead Lake, Mission Range, Swan Lake, and Swan Range. Maps of (b) leaf area index (LAI), (c) annual evapotranspiration, and (d) annual net photosynthesis for the $28 \times 55 \mathrm{~km}$ study area in northwestern Montana, using $1.1-\mathrm{km}$ grid cells defined by the resolution of the NOAA/AVHRR sensor. LAI was estimated by satellite, microclimate data were extrapolated using the MT-CLIM model (Running et al. 1987), and ecosystem processes were calculated using the FOREST-BGC model (Running and Coughlan 1988). See Fig. 2 for an organizational diagram of the data inputs. 

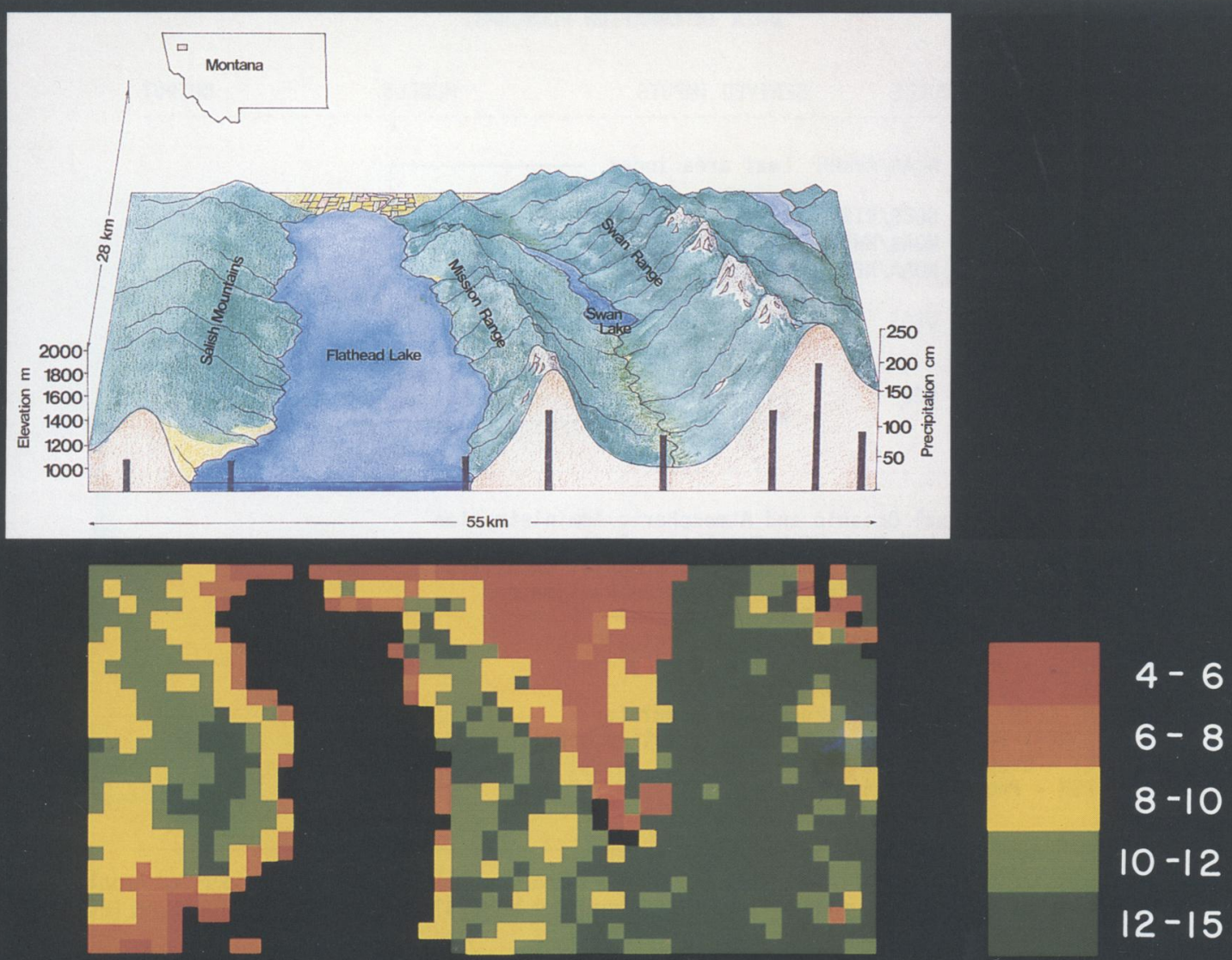

LEAF AREA INDEX

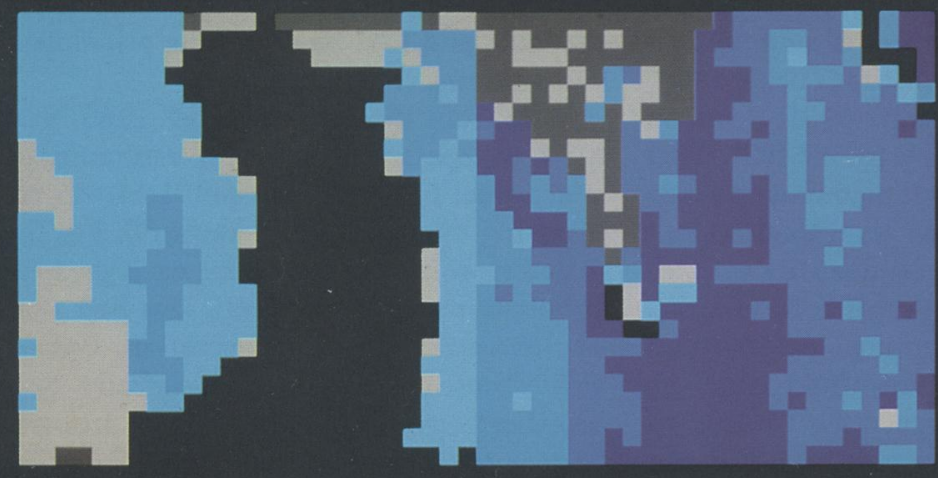

$25-34$

$35-39$

$40-44$

$45-49$

$50-54$

$>55$

EVAPOTRANSPIRATION $(\mathrm{cm} / \mathrm{yr})$

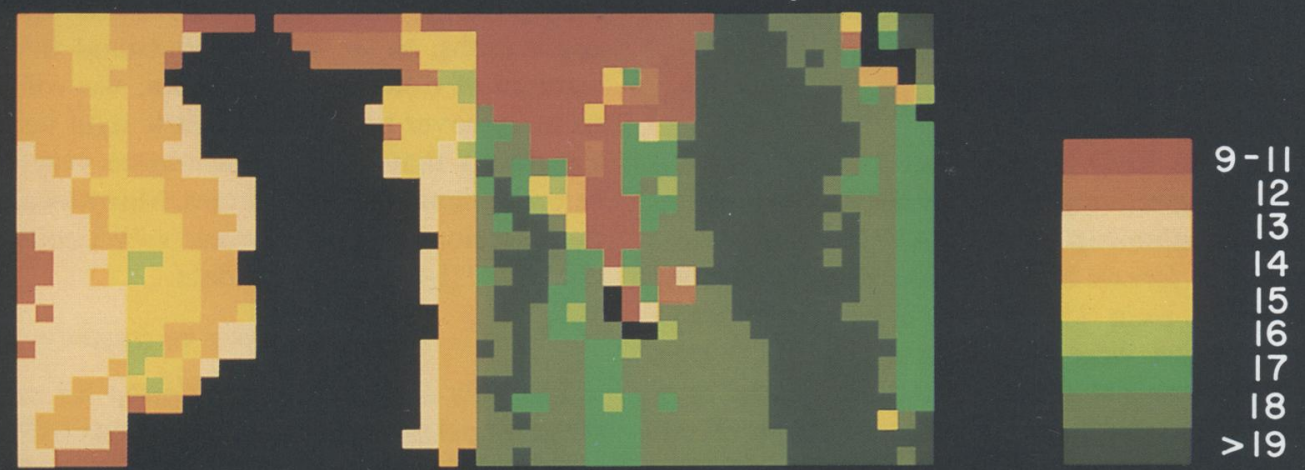

PHOTOSYNTHESIS $\left(\mathrm{Mg} \cdot \mathrm{ha}^{-1} \cdot \mathrm{yr}^{-1}\right)$ 
DATA INTEGRATION FLOWCHART

$\begin{array}{lll}\text { PARAMETER SOURCE } & \text { DERIVED INPUTS } \\ \text { Vegetation } & \text { NOAA/AVHRR } & \text { Leaf area index } \\ \text { Climate } & \begin{array}{l}\text { GOES/NISSR } \\ \text { NOAA/NWS } \\ \text { NOAA/NESS }\end{array} & \begin{array}{l}\text { Solar radiation } \\ \text { Temperature } \\ \text { Precipitation } \\ \text { Elevation } \\ \text { Slope, Aspect }\end{array} \\ \text { Topography } & \text { USGS } & \text { Soil water } \\ \text { Solding capacity }\end{array}$

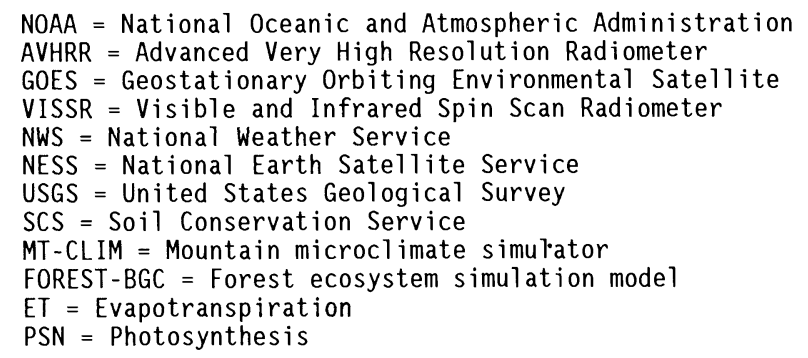

FIG. 2. An organizational diagram showing the sources of raw climatic and biophysical data, the derived variables produced, and their incorporation in the topoclimate (MT-CLIM. Running et al. 1987) and ecosystem simulation (FOREST-BGC, Running and Coughlan 1988) models.

lengths. Previous research has established significant correlations between canopy properties such as leaf area index and NIR/RED combinations (Tucker 1979 , Curran 1983, Asrar et al. 1984, Bauer 1985, Peterson et al. 1987). The underlying principle for the NIR/RED algorithm is as follows: chlorophyll pigments in green leaves absorb radiation in the red wavelengths. Red reflectance is inversely related to the quantity of chlorophyll present in the canopy. On the other hand, nearinfrared radiation is scattered by internal leaf structure and is then either reflected or transmitted, allowing multiple layers of leaves to influence the overall infrared reflectance. The most commonly used NIR and RED combination is called the Normalized Difference Vegetation Index (NDVI), computed as

$$
\text { NDVI }=\frac{(\text { NIR }- \text { RED })}{(\text { NIR }+ \text { RED })}
$$

where NIR and RED are Channel 2 and Channel 1 reflectances, respectively, from AVHRR. We have established a relationship between AVHRR/NDVI and LAI of conifer forests in this region (Fig. 3). Ground measured LAI from 17 conifer forest stands across western Montana were related to a NIR/RED ratio from the Landsat TM sensor with $30-\mathrm{m}$ spatial resolution, and expanded to 53 unmeasured stands of 1.1$\mathrm{km}$ AVHRR/NDVI scale by defining a hydrologic bal- ance between potential evaporation, soil water-holding capacity, and LAI based on the principles in Nemani and Running (1989a).

Data from the 25 September 1985 NOAA-9 1430 MST overpass were used for estimating LAI for the study area. For each grid cell, LAI was computed by inverting the relationship shown in Fig. 3.

Before computing LAI for each grid cell, we used aerial photos to identify cells that had a large number of clearcuts or young regeneration. Because clearcuts and young regeneration are usually dominated by broadleaf species that have spectral properties different from conifers, LAI estimates from NDVI could be erroneously high for these areas. Therefore, the LAI for these grid cells was set to 4.0 , the lowest value. In future applications, as we better understand the reflectance features of different cover types, we will preclassify areas by cover type from satellite data (using channel algorithms that better discriminate vegetation form) before assigning LAI estimates. Many local cover-type classifications have been made with Landsat data, but not with $1.1-\mathrm{km}$ AVHRR data.

\section{Soil water-holding capacity}

The only site parameter required for each grid cell in the model is available water capacity (AWC), defined in this study as soil water content between -0.01 and 


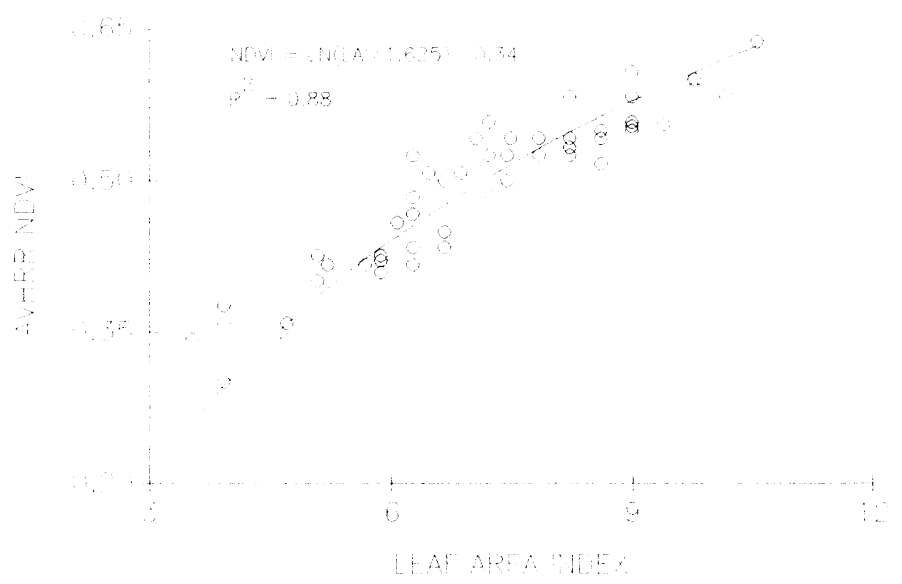

FIG. 3. The relationship between spectral reflectance from the NOAA/AVHRR overpass on 25 September 1985, measured as NDVI, ([NIR - RED)/(NIR + RED]), and projected leaf area index estimated (from ground measurements of 17 stands) for 53 mature conifer forest stands across western Montana using the hydrologic equilibrium theory of Nemani and Running $(1989 a)$.

$-1.5 \mathrm{MPa}$ soil water potential. The Soil Conservation Service (SCS) produced maps of soil series along with data on texture, depth, and AWC for this region. For each grid cell, information on AWC and depth was extracted from these maps and adjusted to total AWC based on soil depth. This estimation technique was used successfully in a previous study where a regression was found of $\mathrm{AWC}_{\text {meas }}=1.03 \cdot \mathrm{AWC}_{\text {est }}-0.65, R^{2}=$ $0.87, \mathrm{SE}=2.2 \mathrm{~cm}$, for six sites in Montana (McLeod and Running 1988). The maximum depth was restricted to $100 \mathrm{~cm}$, because the rooting zone rarely exceeds $100 \mathrm{~cm}$ in these coniferous forests.

Water equivalent snowpack data are critical for beginning model runs, because a major portion of the summer hydrologic cycle is driven by snowmelt in this region (Running 1984). Average monthly snowpack data were obtained from SCS snow surveys. These data were adjusted for each grid cell based on differences in topography and vegetation, and initial snowpacks for day of year 90 were defined ranging from $5 \mathrm{~cm}$ at 1000 $\mathrm{m}$ elevation to $40 \mathrm{~cm}$ at $3000 \mathrm{~m}$ (Parker 1971).

\section{Daily meteorological data}

Although algorithms to produce daily surface temperature and solar radiation from satellite data have been developed by the NOAA/National Earth Satellite Service (Yates et al. 1983), these products have two limitations. First, the satellite data are mapped to a polar stereographic grid, but the size of grid cell is 47 $\times 47 \mathrm{~km}$ at $60^{\circ}$ latitude, i.e., too coarse a spatial scale for our research. Second, over the continental United States, only insolation is derived from satellites because many National Weather Service ground stations do not record incoming radiant energy. Air and dew point temperatures and precipitation are filled from ground weather stations, which are still more accurate than the satellite estimates and are not interrupted by cloud cover. Consequently, we decided to use only in- solation from the NOAA/National Earth Satellite Service database. The rest of our climatic data were obtained from ground stations situated in or around the study area.

Satellite-derived insolation estimates have been tested on flat terrain and found to be within 10\% of ground measurements (Tarpley 1979). However, these radiation estimates have never been tested in mountainous terrain with orographically-induced cloud development. Consequently, we verified their accuracy in mountainous terrain using measured insolation from the central meteorological station at the University of Montana Lubrecht Experimental Forest (LEF), situated $45 \mathrm{~km}$ south of the study area. A linear regression between observed and satellite-estimated insolation for the grid cell enclosing LEF resulted in the following relationship: $Q_{\text {meas }}=0.99 \cdot Q_{\text {sat }}+73.2, R^{2}=0.90$, where $Q_{\text {meas }}$ is ground-measured and $Q_{\text {sat }}$ satellite-estimated daily solar radiation in joules per square centimetre per day. We conclude that insolation can be estimated from satellite-based sensors accurately, even in mountainous terrain.

Maximum and minimum air temperatures and precipitation were collected from National Weather Service stations situated in or near the study area. Dew point temperature was assumed to be equivalent to night minimum air temperature because humidity was not directly measured (Running et al. 1987). The study area was divided into four quadrants and for each quadrant data from the following National Weather Service (NWS) stations were used: Bigfork, Montana (northeast); Kalispell, Montana (northwest); Swan Lake, Montana (southeast); Polson, Montana (southwest).

For each grid cell, these data were extrapolated using MT-CLIM, a microclimate simulation model developed for mountainous terrain by Running et al. (1987). MT-CLIM extrapolates meteorological variables from the point of measurement (referred to as base station) 
to the study site of interest, making corrections for differences in elevation, slope, and aspect between the two sites and improving the time and spatial scaling of data for computation of ecological processes. MTCLIM uses climatological principles to extrapolate base station data to produce site-specific conditions of incident shortwave radiation, daylight average temperature, minimum temperature, daylight average relative humidity, and daily total precipitation.

The model uses the following procedure for estimating daily solar radiation at the base station if radiation has not been recorded. First, potential solar radiation to a flat surface is calculated using sun-earth geometry. An atmospheric transmission coefficient is then computed from base elevation, and a seasonallycorrected cloud cover calculated from daily temperature amplitude. Finally, daily potential radiation is multipled by the atmospheric transmissivity to give actual incident solar radiation. This procedure, developed by Bristow and Campbell (1984), was tested by Running et al. (1987) in this region. The procedure was used to fill in missing days from the satellite-derived solar radiation data, and to interpolate solar radiation data from the $47 \times 47 \mathrm{~km} \mathrm{NOAA/NESS} \mathrm{grid} \mathrm{to} \mathrm{the}$ mountain slopes of each $1.1-\mathrm{km}$ study cell.

Average elevation, slope, and aspect for each grid cell were estimated by overlaying a $1.1-\mathrm{km}$ scale grid sheet on United States Geological Survey (USGS) 1:100 000 topographic maps. The topographic data for each grid cell were used as inputs to MT-CLIM. MTCLIM then extrapolated base station daily meteorological conditions for 1985 to each grid cell, providing site-specific temperature, solar radiation, and humidity estimates. Base station precipitation was adjusted for each grid cell using annual average isohyet maps. We did not consider wind conditions, partly because energy and mass exchange by conifer needles is insensitive to windspeed beyond a rather low threshold (i.e., $0.005 \mathrm{~m} / \mathrm{s}$; Smith 1980), and partly because general climatological principles for extrapolation in mountainous terrain are not available.

Finally, the ecosystem model, FOREST-BGC, was run for each grid cell using estimated LAI from AVHRR, defined soil water capacity, and the derived daily climatic conditions. The simulations were run from day of year 90 to day of year 300. Between day of year 300 and day of year 90, maximum daily air temperatures are almost continuously $<0^{\circ} \mathrm{C}$, so we assumed ET and PSN to be zero for the winter period to save computation time. Annual evapotranspiration and net photosynthesis predicted by the model were mapped to show the spatial variability across the study area.

Ground verification of surface fluxes at $1.1 \mathrm{~km}$ poses substantial logistical problems. Sample sites ideally would be $2.5-3$ times the pixel size, or $\approx 3 \mathrm{~km}^{2}$, and clearly an enormous effort would be required to characterize even a small sample of sites. Consequently, our assessment of the surface fluxes emphasizes the relative spatial variation rather than their absolute accuracy. Hydrologic mass balance estimates of ET for two watersheds in the study area are included, and comparisons of the PSN estimates to field data from another study, to illustrate some confidence in the simulation results.

\section{Results AND Discussion$$
\text { Leaf Area Index (LAI) }
$$

The range of total LAI computed from AVHRR/ NDVI in the study area was 4-15. Field measures of LAI published for coniferous forests in this region are: 4-13 in Montana by Pierce and Running (1988), 2-10 for sites east of the Cascade Mountains of Oregon in Gholz (1982), 3.9-9.9 in Wyoming by Knight et al. (1985), 5.1-6.3 in Montana by Donner and Running (1986), and 5.2-8.4 in Montana by McLeod and Running (1988). Ground verification of LAI at $1.1-\mathrm{km}$ scale is extremely difficult and poses several logistical problems. In a singular attempt, Spanner et al. (1987), using a 28 September 1984 AVHRR scene of the Pacific Northwest, found the simple ratio of NIR/RED reflectances to be highly correlated $\left(R^{2}=0.86\right)$ with LAI of 18 conifer forests. The stands, each $2 \times 2 \mathrm{~km}$, and with measured LAI ranging from 2 to 27 , were located in Oregon, California, Montana, and Washington. The strength of the NIR/RED ratio in estimating LAI of coniferous forests was also shown by Peterson et al. (1987) and Running et al. (1986), but with the Landsat TM at 30-m scale. We emphasize that the strong relationship between LAI and AVHRR/NDVI in Fig. 3 and mapped in Fig. $1 \mathrm{~b}$ is found despite the marked diversity in species, topography, and atmospheric transmissivity of this study area. These results suggest that satellites will be useful in mapping of forest LAI with AVHRR/NDVI for regional scale ecosystem studies.

Leaf area increases with increasing precipitation in the study area (Fig. 1b). Grier and Running (1977) first quantified the link between site water balance and LAI of water-limited coniferous forests in Oregon. The spatial pattern of LAI in Fig. $1 \mathrm{~b}$ reflects the influence of various components of site water balance (precipitation, soil water-holding capacity, and atmospheric evaporative demand) on the NDVI and estimated LAI (Nemani and Running 1989a).

The west-facing slopes of the Swan Range receive the highest precipitation, 100-200 $\mathrm{cm}$, so are able to support high LAI, 10-15 (although LAI above 11 are extrapolations beyond our data in Fig. 3). In contrast, the Salish Mountains, receiving $\approx 60 \mathrm{~cm}$ of precipitation, carry a LAI of 6-9. However, the wide range of LAI seen, for example, on the Swan Range suggests that factors regulating leaf area are more complex than a simple relation to annual precipitation. Capacity to store soil water from spring snowmelt is critical for 
supporting growth in this climate where summer rains are too light and sporadic to recharge soil water. For example, the Mission Range receives higher precipitation than the Salish Mountains, but because steep slopes and shallow soils result in lower soil water-holding capacities, the forests have proportionally low LAI, i.e., 6-9. A large fraction of precipitation leaves the system as outflow and is not available to plants. Model results also indicated that warmer temperatures at lower elevations of the Salish Mountains, by increasing vapor pressure deficits, trigger water stress earlier than for other areas (Fig. 4a). We hypothesize that over time this regular water stress is moderated by reducing forest LAI, and the spatial pattern of our satellite data support this conclusion.

\section{Evapotranspiration (ET)}

Fig. 1d displays the map of annual evapotranspiration computed over the region, ranging from 35 to 60 $\mathrm{cm}$. Evaporation from Flathead Lake was not computed as our analysis is concerned with terrestrial processes. There are only two watersheds in the study area that are hydrologically well characterized and useful for validating these estimated ET. Sullivan Creek (USGS Station Number 12361000), is a $185-\mathrm{km}^{2}$ watershed flowing east from the Swan Range. Mean annual precipitation is $152 \mathrm{~cm}$ and stream discharge is $109 \mathrm{~cm}$, giving an average ET estimated at $43 \mathrm{~cm}$, compared to our estimate of $40-49 \mathrm{~cm}$. The Swan River (USGS Station Number 12369200) drains a $179 \mathrm{~km}^{2}$ area flowing north into Swan Lake. Annual precipitation averages $137 \mathrm{~cm}$ and streamflow $82 \mathrm{~cm}$, producing an ET estimate of $55 \mathrm{~cm}$, compared to our estimate of $>55 \mathrm{~cm} / \mathrm{yr}$. In both cases we are comparing our ET estimate for 1985 against long-term averages from USGS data. However, 1985 was within 12\% of normal in precipitation and temperature in this area.

Fig. 1d illustrates the influence of land use on ET. The area north of Swan Lake shows the lowest ET in the study area due to the low LAI of young regeneration following clear-cutting. The seasonal trajectory of ET during the growing season is also quite different within this region (Fig. 4b). Forests on the Salish Mountains showed maximum rates of ET during early summer, while on the Swan Range maximum ET occurred during mid- to late summer. Snowmelt is earlier at lower elevations, and higher evaporative demands lead to accelerated soil moisture depletion. Canopy water stress starts much earlier in the Salish Mountains. On 1 July (day of year 180), the average predawn leaf water potential simulated for the Salish Mountains is $-1.4 \mathrm{MPa}$, compared to $-0.5 \mathrm{MPa}$ in the Swan Range (Fig. 4a). Conversely, forests on the Swan Range continue to transpire through much of the growing season without undergoing significant soil water deficits, accumulating higher ET. However, higher elevations show slightly lower ET because of lower air temperature rather than lack of adequate soil moisture.
Summer precipitation in this region results in little soil water recharge (Running and Nemani 1985). Most of the precipitation received during summer is lost to canopy interception. Forests on the Swan Range with LAI $>10$ need $>5 \mathrm{~mm}$ of rain before any soil recharge is possible (Knight et al. 1985). This lack of soil recharge during summer emphasizes the importance of spring snowpack and soil water-holding capacity for storing spring snowmelt. The differences in ET seen across the Mission Range down to the Swan Valley are partially a function of soil characteristics in the study area. AWC ranged between 14 and $20 \mathrm{~cm}$ in the Mission Mountains, compared to $25-30 \mathrm{~cm}$ in the Swan Valley.

Although the accuracy of ET estimates at regional scales is difficult to determine, we have validated similar water balance simulations against stand-level field data in previous studies. Donner and Running (1986) successfully simulated both the timing and absolute magnitude of seasonal predawn leaf water potentials to within -0.2 MPA of measured data in a Pinus contorta stand at the Lubrecht Experimental Forest 100 $\mathrm{km}$ south of the study area. Nemani and Running (1989a) also successfully simulated seasonal soil moisture depletion of a thinned and unthinned Pinus contorta stand at the Lubrecht Forest. Correlations between predicted and observed daily soil moisture were $R^{2}=0.90$ for the control and $R^{2}=0.93$ for the thinned stand for days of year 120-300.

Our biophysical analysis of regional ET has several advantages over the more common aerodynamic or energy-budget approaches (Brutsaert 1986) or hydrologic mass balances, that can only be calculated annually and provide no explicit sensitivity to plant physiological controls. We include soil moisture as a system storage component, whereas approaches like PriestleyTaylor do not. With our process model, we also calculate daily physiological restrictions to ET from stomatal closure, defined by surface resistance. In conifer forests, ET is driven primarily by vapor pressure deficits imposed by the regional atmospheric conditions, and the spatial variation in ET is predominately a function of surface resistance (Jarvis and McNaughton 1986). Surface resistance is a function of LAI, humidity, and soil water availability. Accurate estimates of LAI and inclusion of soil properties are critical for understanding land-atmosphere interactions in global circulation models (Sellers et al. 1986, Wilson et al. 1987).

\section{Net Photosynthesis (PSN)}

The FOREST-BGC model estimated annual PSN (measured as C) ranging from 9 to $20 \mathrm{Mg} \cdot \mathrm{ha}^{-1} \cdot \mathrm{yr}^{-1}$ across the study area (Fig. 1c). Obviously, we can offer no direct validation for PSN rates from $1.1-\mathrm{km}$ cells. However, using field data from a previous study (McLeod and Running 1988) on six sites near this study area, we found a $R^{2}=0.94$ relating simulated annual 


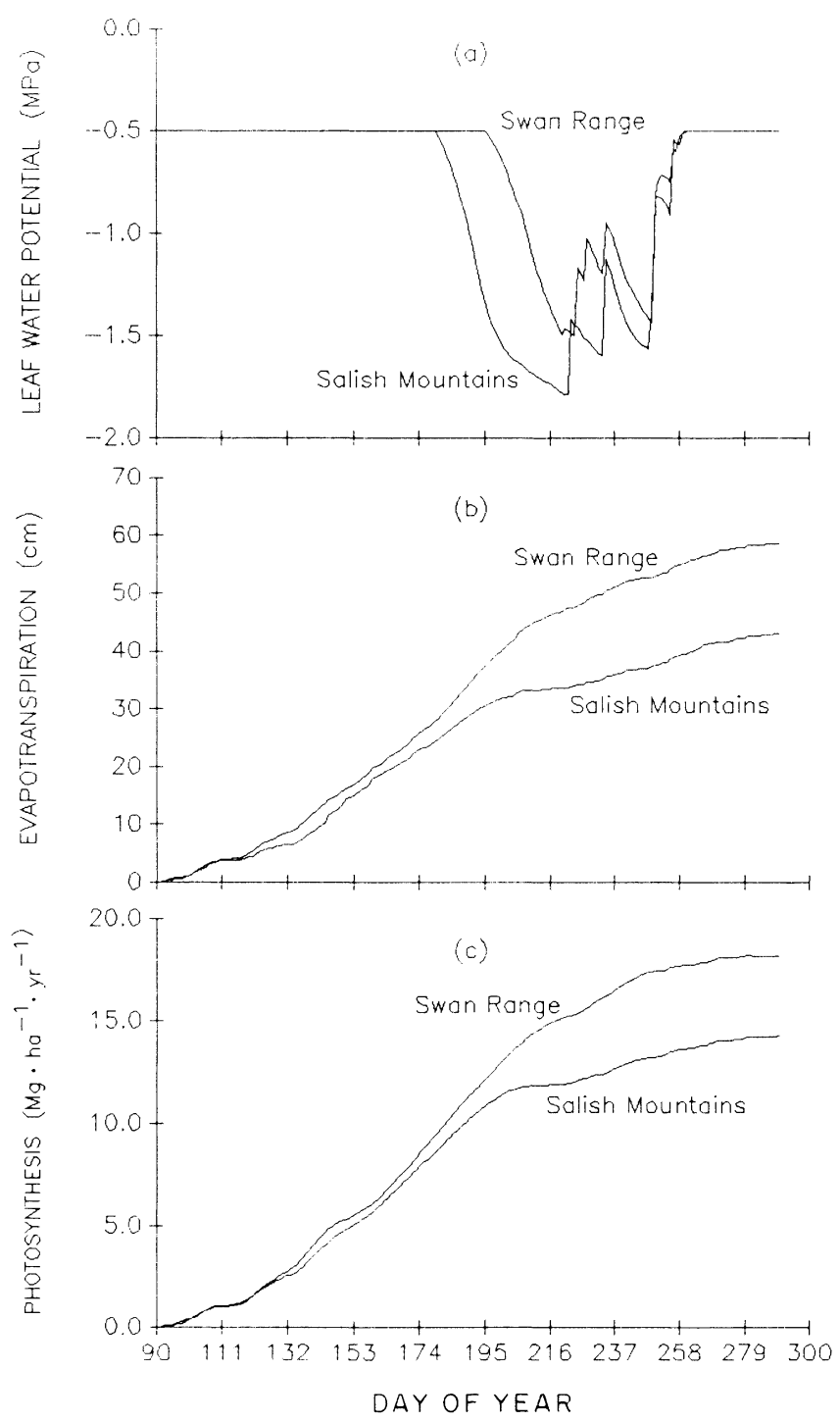

FIG. 4. Seasonal trends for 1985 of (a) predawn canopy water potential, (b) cumulative evapotranspiration, and (c) cumulative net photosynthesis simulated by FOREST-BGC for a high (Swan Range) and low (Salish Mountain) activity cell in the study area in western Montana (see Fig. 1). The high-activity Swan Range cell had LAI $=12.0$ and soil water capacity $=30 \mathrm{~cm}$, while the low-activity Salish Mountain cell had LAI $=8.0$ and soil water capacity $=22 \mathrm{~cm}$.

photosynthesis and observed stem volume growth (Fig. 5). We justify this relation between annual photosynthesis and stem volume growth as reasonable by certain assumptions about tree carbon allocation. We can translate the simulated 9-20 Mg.ha ${ }^{1} \cdot \mathrm{yr}^{1} \mathrm{PSN}$ to aboveground dry biomass by conversions for dry matter per gram of carbon and by assuming $40 \%$ belowground carbon allocation and $35 \%$ growth respiration costs (Running and Coughlan 1988). Our estimate of $8-17 \mathrm{Mg} \cdot \mathrm{ha}^{-1} \cdot \mathrm{yr}^{-1}$ of aboveground net primary production (ANPP) is reasonable for western coniferous forests (Grier et al. 1981, Gholz 1982). We next assume stem production to be $50 \%$ of total aboveground NPP and a wood specific gravity of $0.5 \mathrm{~g} / \mathrm{cm}^{3}$. The resulting stem volume growth estimate ranges from
8 to $17 \mathrm{~m}^{3} \cdot \mathrm{ha}^{-1} \cdot \mathrm{yr}^{-1}$, higher than the $Y$-axis of Fig. 5 , but reasonable because the sites measured by McLeod and Running (1988) were drier than in the present study area. An assumed belowground carbon allocation of $60 \%$ found by Keyes and Grier (1981) and Agren et al. (1980) in other conifer forests would yield $5-11 \mathrm{~m}^{3} \cdot \mathrm{ha}^{-1} \cdot \mathrm{yr}^{-1}$ of stem volume growth, almost exactly fitting the data in Fig. 5. Because carbon allocation patterns, respiration losses, and wood specific gravity probably all vary within this study area, we are most comfortable offering only the annual PSN map of Fig. 1c. However, these PSN data can be translated into reasonable ANPP or stem volume growth estimates. Most critically, ANPP or stem volume growth data could be measured to provide some direct vali- 
dation of the PSN map, although the cost of that regional field sampling would be high.

The maps of LAI and PSN show similar patterns across the landscape. The lowest amount of PSN is from the young regeneration north of Swan Lake, because of low LAI in this area. The highest PSN is found at the midelevation slopes on the Swan Range. Within a zone of similar LAI, for example on the Swan Range, there were notable differences in computed PSN resulting from differences in local temperature and solar radiation. While water deficits restricted photosynthesis on the Salish Mountains, forests on the Swan Range did not undergo significant water stress (Fig. 4c). Midelevations showed highest PSN because moderate temperatures allowed for a better photosynthesis-respiration balance. While the low-elevation forests suffered increased losses in maintenance respiration due to warmer temperatures, low temperatures at higher elevations restricted PSN, both conditions resulting in lower PSN. Variable water supply also contributed significantly to the spatial variation of PSN over the study area. Forests on the Salish Mountains had much higher PSN rates compared to other areas during the early part of the growing season. However, high evaporative demand and transpiration (caused by warmer temperatures) forced the trees to expend the limited amount of moisture by mid-August. In the absence of significant soil recharge during the summer, trees were under such high water stress (Fig. 4a) that PSN did not increase substantially for the rest of the growing season. Conversely, higher water availability on the Swan Range sustained positive PSN rates throughout the growing season.

\section{FUTURE IMPROVEMENTS}

We suggest that major improvements in regional estimates of vegetation processes are possible by coupling ecosystem simulation with remote-sensing data. However, to be operationally feasible and efficient several aspects of this methodology need development. Choice of scale is one of the most difficult problems in landscape estimation of surface fluxes. A major consideration in the analysis of ET and PSN on a regional basis is the scale at which the internal mechanisms are parameterized. Theoretically, this scale should be determined by the complexity and causal controls of the subscale phenomenon. However for vegetation processes, one could argue that the fundamental resolution of the system is the individual organism, and mechanistic controls of the processes are primarily determined by the internal physiology of trees. Clearly, treeby-tree simulations over whole regions are not possible or desirable; some level of abstraction of the ecosystem is necessary. This abstraction of tree physiology leads to the development of rather unusual variables, such as the stomatal conductance of an entire watershed, yet meteorologists and hydrologists have calculated surface resistances on these scales for years without
FIG. 5. The correlation found between annual net photosynthesis (PSN, measured as C) simulated by FORESTBGC and measured stem volume growth for six Pinus ponderosa stands in western Montana (growth data from McLeod and Running 1988). The regional PSN map of Fig. Id cannot be directly validated. but this strong relationship to observed growth suggests that the spatial patterns of PSN illustrated may represent relative magnitudes of growth well, providing realistic patterns of forest productivity for this region.

including physiological feedback mechanisms. We feel these biological abstractions are most explicitly done by an ecosystem simulation model. Extrapolation of the model is enhanced by designing it to be operated with the available remote-sensing inputs, preferably using a geographic information system as initial data template.

Scale is often imposed simply by the available data for the study, such as the LAI from AVHRR in this study. Alternatively, we could have used spectral data from the 30-m TM for LAI analysis, but this would have generated 1.33 million pixels in our study area rather than the 1200 from AVHRR. The maps in Fig. $\mathrm{lb}-\mathrm{d}$ required $5 \mathrm{~h}$ for the microclimate calculations and $5 \mathrm{~h}$ for the ecosystem calculations for the 1200 grid cells on an IBM Model 80 microcomputer. Extrapolation of this logic to larger scales would be constrained by computer resources.

Similar approaches may also be applied when extrapolating regional estimates of processes like ET and NPP for global applications. For example, analysis of our study area shows that the entire landscape could have been divided into seven units: west- and eastfacing slopes of the three mountain ranges and the Swan Valley. Such an aggregation would have substantially reduced the number of computations, while the estimates might still have reflected the vegetationatmosphere interactions adequately for purposes such as the global circulation models. Consequently, we are now developing algorithms that will aggregate landscape units that can be considered homogeneous in the variables of interest, for example, topography, soils, LAI, and species type, using TM or MSS pixels as basic units. Such segmentation of the landscape allows the measurement, parameterization, and simulation to be carried out singly for extensive, uniform forest stands, 
rather than pixel by pixel as was done in this study. Clearly continental scale analyses must find more efficient computational approaches. Such an approach also provides a mechanism to go from a plot level to a continental scale, while knowing what losses in information are occurring as aggregation proceeds from small to larger areas (Badhwar et al. 1986).

The FOREST-BGC model is designed to emphasize LAI as the primary definition of the vegetated surface, because LAI is one of the few vegetation variables that can be measured by remote sensing. Errors in LAI can lead to significant discrepancies in estimated fluxes of ET and PSN. We emphasize that the LAI map of the study area is adequate for showing relative differences but absolute values have not been validated. The relationship between NDVI and LAI used in this study was developed for mature, extensive forests where spatial variation is usually small. In a normal landscape, however, the presence of grass, shrubs, and broadleaf trees affects reflected irradiance differently than seen for conifer trees.

Techniques for estimating surface radiation, temperature, humidity, and precipitation from satellite sensors are at various stages of development and testing (Suskind et al. 1984). Current products are restrained by cloud cover and produce estimates at $50 \times 50 \mathrm{~km}$ scales requiring interpolation for use at more local scales. Computations of ET and PSN are highly influenced by the accuracy of the meteorological data used, yet extrapolation techniques for surface meteorology are not perfected, particularly for daily precipitation (Running et al. 1987). Estimates of bulk surface resistance of vegetated surfaces from visible and infrared satellite observations (Goward et al. 1985, Nemani and Running $1989 b$ ) now appear possible and may allow much simplified regional models of ET and PSN.

Ground validations at regional scales are a fundamental problem that may be best addressed by a hierarchy of measurements from ground to Landsat Thematic Mapper to AVHRR (Badhwar et al. 1986, Running and Nemani 1988). Although we acknowledge shortcomings of this approach, we see few alternatives for bridging the gap between empirical models used at global scales and highly detailed analytica' models suitable only at the tree or stand level.

The ability to map LAI dynamically by satellite, and to calculate ET and PSN at 1.1-km scale over hundreds of square kilometres, suggests that we can now begin to explore the consequences of regional climatic change, land-use change, pollution episodes, and other perturbations on energy and mass exchange rates of the biosphere.

\section{ACKNOWLEDGMENTS}

This research was funded by the National Aeronautics and Space Administration Earth Science and Applications Division through grant Number NAGW-952. Ames Research Center Joint Research Interchanges Number NCA 2-27 and 2-138, and McIntire-Stennis funding to the School of For- estry, University of Montana. We thank Drs. D. Kang, R. Wakimoto, and $\mathrm{H}$. Zuuring for review of the draft manuscript.

\section{Literature Cited}

Agren, G. I., B. Axelsson, J. G. K. Flower-Ellis, S. Linder, H. Persson, H. Staff, and E. Troeng. 1980. Annual carbon budget for a young Scots pine. Ecological Bulletins-NFR 32:307-313.

Asrar, G., M. Fuchs, E. T. Kanemasu, and J. L. Hatfield. 1984. Estimating absorbed photosynthetic radiation and leaf area index from spectral reflectance in wheat. Agronomy Journal 76:300-306.

Badhwar, G. D., R. B. MacDonald, and N. C. Mehta. 1986. Satellite-derived leaf-area-index and vegetation maps as input to global carbon cycle models - a hierarchial approach. International Journal of Remote Sensing 7:265-281.

Band, L. E., O. B. Elfes, J. T. Hayes, L. O. Mearnes, P. A O’Rourke, B. J. Stevenson, W. H. Terjung, and P. E. Todhunter. 1981. Application of a photosynthesis model to an agricultural region of varied climates in California. Agricultural Meteorology 24:201-217.

Bauer, M.E. 1985. Spectral inputs to crop identification and condition assessment. Proceedings of the Institute of Electrical and Electronic Engineers 73:1071-1085.

Botkin, D. B.. chair. 1986. Remote sensing of the biosphere. Report of the committee on planetary biology. National Academy of Sciences, Washington D.C., USA.

Bristow. K. L., and G. S. Campbell. 1984. On the relationship between incoming solar radiation and daily maximum and minimum temperature. Agricultural and Forest Meteorology 31:159-166.

Brutsaert, W. 1986. Catchment-scale evaporation and the atmospheric boundary layer. Water Resources Research 22: 39S-45S.

$\rightarrow$ Curran, P. J. 1983. Multispectral remote sensing for the estimation of green leaf area index. Philosophical Transactions of the Royal Society of London 309:257-270.

Donner, B. L.. and S. W. Running. 1986. Water stress response after thinning Pinus contorta stands in Montana. Forest Science 32:614-625.

Dunin, F. R., and A. R. Aston. 1984. The development and proving of models of large scale evapotranspiration: an Australian study. Agricultural Water Management 8:305-323.

Emmanuel, W. R., G. G. Killough, W. M. Post, and H. H. Shugart. 1984. Modeling terrestrial ecosystems in the global carbon cycle with shifts in carbon storage capacity by landuse change. Ecology 65:970-983.

Gholz. H. L. 1982. Environmental limits on aboveground net primary production, leaf area, and biomass in vegetation zones of the Pacific Northwest. Ecology 63:469-481.

Golkin, K., and K. C. Ewel. 1984. A computer simulation of the carbon, phosphorus, and hydrologic cycles of a pine flatwoods ecosystem. Ecological Modelling 24:113-136.

Goward, S. N., C. J. Tucker, and D. G. Dye. 1985. North American vegetation patterns observed with the NOAA-7 advanced very high resolution radiometer. Vegetatio 64:314.

Grier, C. C., and S. W. Running. 1977. Leaf area of mature northwestern coniferous forests: relation to site water balance. Ecology 58:893-899.

Grier, C. C., K. A. Vogt, M. R. Keyes, and R. L. Edmonds. 1981. Biomass distribution and above- and below-ground production in young and mature Abies amabilis zone ecosystems of the Washington Cascades. Canadian Journal of Forest Research 11:155-167.

Hayes, L. 1985. The current use of TIROS-N series of meteorological satellites for land-cover studies. International Journal of Remote Sensing 6:35-45.

Jarvis, P. G., and K. G. McNaughton. 1986. Stomatal control of transpiration. Scaling up from leaf to region. Advances in Ecological Research 15:1-49. 
Justice, C. J., J. Townsend, B. Holben, and C. Tucker. 1985. Analysis of the phenology of global vegetation using meteorological satellite data. International Journal of Remote Sensing 6:1271-1318.

Keyes, M. R., and C. C. Grier. 1981. Above- and belowground net production in 40-year-old Douglas-fir stands on high and low productivity sites. Canadian Journal of Forest Research 11:599-605.

Knight. D. H., T. J. Fahey, and S. W. Running. 1985. Water and nutrient outflow from contrasting lodgepole pine forests in Wyoming. Ecological Monographs 55:29-48.

Leith, H. 1975. Modeling the primary productivity of the world. Pages 237-267 in H. Leith and R. H. Whittaker. editors. Primary productivity of the biosphere. SpringerVerlag, New York, New York. USA.

Manabe, S., and R. T. Wetherald. 1980. On the distribution of climate change resulting from an increase in $\mathrm{CO}_{2}$ content of the atmosphere. Journal of Atmospheric Science 37:99118.

Mathews, E. 1983. Global vegetation and land use: new high-resolution data bases for climate studies. Journal of Climate and Applied Meteorology 22:474-500.

McLeod. S. D., and S. W. Running. 1988. Comparing site quality indices and productivity in Ponderosa pine stands in western Montana. Canadian Journal of Forest Research 18:346-352.

Mohren, G. M. J., C. P. Van Gerwen, and C. J. T. Spitters. 1984. Simulation of primary production in even-aged stands of Douglas-fir. Forest Ecology and Management 9:27-49.

Moore, B., R. D. Boone, J. E. Hobbie, and R. A. Houghton. 1981. A simple model for analysis of the role of terrestrial ecosystems in the global carbon budget. Pages 365-385 in B. Bolin, editor. Carbon cycle modelling SCOPE 16. John Wiley \& Sons, New York, New York, USA.

Nemani, R. R., and S. W. Running. 1989a. Testing a theoretical climate-soil-leaf area hydrologic equilibrium of forests using satellite data and ecosystem simulation. Agricultural and Forest Meteorology 44:245-260.

Nemani, R. R., and S. W. Running. 1989b. Estimating regional surface resistance to evapotranspiration from NDVI and Thermal-IR AVHRR data. Journal of Climate and Applied Meteorology 28:276-294.

Norwine, J., and D. H. Greegor. 1983. Vegetation classification based on AVHRR satellite imagery. Remote Sensing of Environment 13:69-87.

Parker, P. E. 1971. Terrain and cover effects on snowmelt in a western white pine forest. Forest Science 17:125-134.

Pastor, J., and W. M. Post. 1986. Influence of climate, soil moisture, and succession on forest carbon and nitrogen cycles. Biogeochemistry 2:3-27.

Peterson, D. L., M. A. Spanner, S. W. Running, and K. B. Teuber. 1987. Relationship of Thematic Mapper Simulator data to leaf area index of temperate coniferous forests. Remote Sensing of Environment 22:323-341.

Pierce. L. L., and S. W. Running. 1988. Rapid estimation of coniferous forest leaf area index using a portable integrating radiometer. Ecology 69:1762-1767.

Running. S. W. 1984. Microclimate control of forest productivity: analysis by computer simulation of annual photosynthesis/transpiration balance in different environments. Agricultural and Forest Meteorology 32:267-288.

1986. Global primary production from terrestrial vegetation: estimates integrating satellite remote sensing and computer simulation technology. Science of the Total Environment 56:233-242.

Running, S. W., and J. C. Coughlan. 1988. A general model of forest ecosystem processes for regional applications. I. Hydrologic balance, canopy gas exchange and primary production processes. Ecological Modelling 42:125-154.
Running, S. W., and R. R. Nemani. 1985. Topographic and microclimate control of simulated photosynthesis and transpiration in coniferous trees. Eidgenoessische Anstalt Forstliche Versuchswesen, Mitteilungen 270:53-60.

Running, S. W., and R. R. Nemani. 1988. Relating seasonal patterns of the AVHRR vegetation index to simulated photosynthesis and transpiration of forests in different climates. Remote Sensing of Environment 24:347-367.

Running. S. W., R. R. Nemani, and R. D. Hungerford. 1987. Extrapolation of synoptic meteorological data in mountainous terrain, and its use for simulating forest evapotranspiration and photosynthesis. Canadian Journal of Forest Research 17:472-483.

Running. S. W., D. L. Peterson, M. A. Spanner, and K. B. Teuber. 1986. Remote sensing of coniferous forest leaf area. Ecology 67:273-276.

Sellers, P. J., F. G. Hall, G. Asrar, D. E. Strebel, and R. E. Murphy. 1988. The first ISLSCP field experiment (FIFE). Bulletin of the American Meteorological Society 69:22-28.

Sellers, P. J., Y. Mintz, Y. C. Sud, and A. Dalcher. 1986. A simple biosphere model $(\mathrm{SiB})$ for use with general circulation models. Journal of Atmospheric Science 43:505-531.

Shukla, J., and Y. Mintz. 1982. Influence of land-surface evapotranspiration on the Earth's climate. Science 215: 14981501.

Smith. W. K. 1980. Importance of aerodynamic resistance to water use efficiency in three conifers under field conditions. Plant Physiology 65:132-135.

Spanner. M. A., D. L. Peterson. S. W. Running, and L. Pierce. 1987. The relationship of AVHRR data to the leaf area index of western coniferous forests. Pages 358-360 in Space Life Sciences Symposium: Three Decades of Life Sciences Research in Space, 21-26 June. National Aeronautics and Space Administration. Washington, D.C., USA.

Suskind. J., J. Rosenfield, D. Reuter, and M. T. Chahine. 1984. Remote sensing of weather and climate parameters from HIRS2/MSU on TIROS-N. Journal of Geophysical Research 89:4677-4697.

Tarpley, J. D. 1979. Estimating incident solar radiation at the surface from geostationary satellite data. Journal of Applied Meteorology 18:1172-1181.

Tarpley. J. D., S. R. Schneider, and R. L. Money. 1984. Global vegetation indices from the NOAA-7 meteorological satellite. Journal of Climate and Applied Meteorology 23:491-494.

Terjung. W. H., S. S-F. Louie, and P. A. O'Rourke. 1976. Toward an energy budget model of photosynthesis for predicting world productivity. Vegetatio 32:31-53.

Tucker. C. J. 1979. Red and photographic infrared linear combinations for monitoring vegetation. Remote Sensing of Environment 8:127-150.

Tucker. C. J., J. R. G. Townsend, and T. E. Goff. 1985. African land cover classification using satellite data. Science 227:369-374.

Wilson. M. F.. A. Henderson-Sellers, and R. E. Dickinson. 1987. Sensitivity of Biosphere-Atmosphere-TransferScheme (BATS) to the inclusion of variable soil characteristics. Journal of Climate and Applied Meteorology 26:341363.

Wittwer, S.. editor. 1983. Land-related global habitability science issues. NASA Technical Memorandum $\mathbf{8 5 8 4 1}$.

Woodwell, G. M., J. E. Hobbie. R. A. Houghton, J. M. Melillo, B. Moore, B. J. Peterson, and G. R. Shaver. 1983. Global deforestation: contribution to atmospheric carbon dioxide. Science 222:1081-1086.

Yates, H. W.. J. Tarpley, S. Schneider. D. McGinnis, and R. Scofield. 1983. The role of meteorological satellites in agricultural remote sensing. Remote Sensing of Environment 14:219-234. 